\title{
Tinjauan Hutang Negara dalam Perspektif Islam
}

\author{
Malikul Hafiz Alamsyah \\ Universitas Pembangunan Nasional Veteran Jakarta \\ malikul.alamsyah@gmail.com \\ Fani Ramadhani \\ Universitas Pembangunan Nasional Veteran Jakarta \\ faniramadhani30@gmail.com \\ Nur Azizah \\ Universitas Pembangunan Nasional Veteran Jakarta \\ azizahzah09@gmail.com
}

Received: August 6, 2020 | Accepted: August 8, 2020 | Published: August 11, 2020

\begin{abstract}
Currently, almost all countries use debt as a source of development financing. Especially for developing countries, debt is quite an important financing instrument. In Islam, the concept of debt is translated into a loan, but with no additional elements that will lead to the practice of usury. This study aims to examine the concept of debt in the Islamic economic system that is practiced by several countries including Indonesia. This study also examines the application of Islamic economic principles related to debt practices that are free from usury practices. This study uses a qualitative approach by describing theories related to debt as well as Islamic views on forests. This study concludes that Islam does not prohibit debt transactions, both in terms of individual practices and practices within the state. However, debt practice must still refer to the contract mechanism following Islamic norms and values. So that debt can be used as a financing instrument in the state development to target people's welfare. So it is hoped that the debt policy implemented by the state is oriented towards the welfare of the community in general.
\end{abstract}

Keywords: Debt; Nation; Islamic Economy

\begin{abstract}
Abstrak
Saat ini hampir seluruh negara menggunakan hutang sebagai salah satu sumber pembiayaan pembangunan. Terlebih bagi negara-negara berkembang, hutang menjadi instrumen pembiayaan yang cukup penting. Di dalam Islam, konsep hutang dijabarkan dalam bentuk pinjaman, namun dengan batasan tidak adanya unsur tambahan yang akan membawa kepada praktik ribawi. Kajian ini bertujuan untuk mengkaji konsep hutang dalam sistem ekonomi Islam yang dipraktekkan oleh beberapa negara termasuk Indonesia. Kajian ini juga mengkaji penerapan prinsip-prinsip ekonomi Islam terkait praktik hutang yang terbebas dari praktik ribawi. Kajian ini menggunakan pendekatan kualitatif dengan menjabarkan teori-teori terkait hutang serta tinjauan Islam terhadap hutan. Kajian ini menyimpulkan bahwa Islam tidak melarang transaksi hutang, baik dalam hal praktik individu, maupun praktik dalam bernegara. Namun demikian, praktik hutang tersebut harus tetap mengacu kepada mekanisme akad yang sesuai dengan norma dan nilai Islam. Sehingga hutang dapat dimanfaatkan sebagai salah satu instrumen pembiayaan dalam pembangunan negara untuk menargetkan kesejahteraan masyarakat. Sehingga diharapkan kebijakan hutang yang diterapkan oleh negara berorientasi pada kesejahteraan masyarakat secara umum.
\end{abstract}

Kata kunci: Hutang; Negara; Ekonomi Islam 


\section{PENDAHULUAN}

Pada dasarnya dalam kebijakan hutang luar negri suatu Negara ialah suatu sumber pembiayaan pembangunan untuk Negara itu sendiri. Apalagi untuk negara berkembang hal ini merupakan suatu sumber pembiayaan pembangunan yang cukup signifikan bagi negara tersebut. Namun memang beberapa hasil studi mengatakan bahwa dari dampak hutang terhadap pembangunan ekonomi untuk suatu negara tersebut menujukkan hasil yang berbeda. Beberapa para ahli mengatakan bahwa hutang luar negeri yang terlalu berlebihan atau terlalu besar, akan membuat perlambatan suatu pertumbuhan ekonomi di negara itu sendiri. Namun dari hasil penelitian yang lain mengatakan dengan adanya hutang luar negri tersebut membuat faktor yang signifikan untuk mendorong pertumbuhan ekonomi negara penghutang tersebut (Choirunnisak, 2018:207-209). Dalam hal ini banyak negara berkembang ataupun negara yang dalam tahapan sedang berkembang melakukan suatu kebijakan hutang ini untuk pertumbuhan ekonomi di Negaranya. Namun hal ini menjadi suatu jebakan sendiri untuk negara tersebut serta membuat negara tersebut masuk dalam lingkaran akan ketergantungan dengan hutang (Kaminsky, 1996:221).

Kondisi pembangunan ekonomi di Indonesia sendiri pada tahuan 1990-an sempat diterpa dengan krisis moneter, hal ini sangat mengguncang sekali perekonomian Indonesia. Dengan adanya krisis ekonomi pada tahun 1997 tersebut membuat Indonesia terus menerus dihantui oleh beban hutang luar negri yang terus menerus bertambah setiap tahunnya. Pembangunan ekonomi di Indonesia ini ditopang oleh hutang luar negri dengan jumlah yang terus meningkat. Kondisi pembangunan ekonomi di Indonesia memang tidak dapat dipungkiri bahwa ditopang oleh pinjaman luar negri dengan jumlah yang tidak sedikit dan terus meningkat.

Menurut Jefrey A. Winters seorang ekonom dari Northwestern University AS mengatakan bahwa sepertiga yang diperoleh dari bantuan Bank Dunia untuk Indonesia bocor di birokrasi Indonesia. Menurut hasil survey Transparancy International terkait bantuan pinjaman Bank Dunia terhadap 52 Negara, Indonesia menempati peringkat ke 7 dan di antara Negara ASEAN berada pada peringkat pertama (Hamid, 2000: 74-75).

Berdasarkan data yang dilakukan oleh Kementerian Keuangan, mencatat posisi hutang pemerintah terhadap luar negeri per akhir Januari 2020 sebesar Rp 4.817,55 triliun (Makki, 2020). Dalam hal ini terjadi peningkatan jumlah hutang pemerintah pada bulan januari 2020 dibanding dengan periode yang sama pada tahun sebelumnya sebesar Rp 4.498,56 triliun. Serta Kemenkeu juga mencatat defisit anggaran sebesar Rp 36,1 triliun pada Januari 2020. Oleh karena itu untuk menutup defisit anggaran tersebut, pemerintah melakukan skenario pembiayaan 
hutang yang mencapai Rp 68,2 triliun sekitar 19,4 persen dari target APBN sampai akhir Januari 2020.

Dalam Islam terdapat dua pandangan mengenai hutang luar negeri dalam perspektif pembiayaan pembangunan negara. Pandangan pertama memperbolehkan adanya suatu budget deficit yang ditutup dengan external financing, dimana bentuk dan mekanismenya tersebut sudah disesuaikan dan tidak bertentangan dengan ketentuan/prinsip syariah. Dari adanya fakta historis bahwa bekerjasama dengan pihak lain dalam suatu usaha diperbolehkan, bahkan dianjurkan. Seperti dengan penggunaan akad mudharabah, musyarakah, murabahah, dan lain-lain, dapat dikembangkan sebagai bentuk external financing dalam anggaran negara. Dibandingkan dengan hutang, penyertaan modal ini dipandang lebih, konstruktif, proporsional dan adil dalam pembiayaan, karena terdapat pembagian perolehan dan resiko (profit-loss sharing). Kemudiaan untuk pandangan yang ke dua ialah negara tidak diperbolehkan menutup budget deficit dengan melakukan hutang luar negeri. Karena pada pertimbangan preventif bahwa mekanisme pinjaman hutang luar negeri menggunakan sistem bunga, sedangkan dalam islam, bunga dalam bentuk apapun baik konsumsi atau produksi dan besar atau kecil secara tegas dilarang.

Dari persoalan-persoalan yang telah dijelaskan di atas ini menarik penulis untuk membahas serta mengkaji lebih lanjut mengenai bagaimana kebijakan hutang dalam pembangunan ekonomi Islam. Hal ini akan terlihat bagaimana kebijakan hutang jika dlihat dari pembangunan ekonomi Islam, konsep hutang dalam Islam, hutang suatu negara, serta dampak, resiko, dan bahaya dalam berhutang.

\section{TINJAUAN PUSTAKA}

\section{A. Konsep Hutang dalam Islam}

Dalam bahasa Arab, hutang (al-dayn) merupakan sesuatu yang berada dalam tanggung jawab orang lain. Menurut Hanafiyah, dayn termasuk kepada al milk. hutang dapat dikategorikan pada al-Mal al-Hukmi yaitu sesuatu yang dimiliki oleh pemberi hutang, sementara harta itu berada pada orang yang berutang. Sehingga hutang negara adalah milik rakyat dan dipergunakan untuk keperluan rakyat. Selain itu, hutang secara bahasa hutang juga dapat bermakna memberikan pinjaman. Al-dayn mensyaratkan jangka waktu tertentu dalam pengembalian hutang, hal ini yang membedakan qardh yang tidak mensyaratkan jangka waktu tertentu dalam pengembalian hutangnya, dayn lebih umum dari qardh.

Di dalam Al-Quran dan hadits, Allah dan Rasul-Nya memerintahkan agar saling membantu sesama dalam pinjam meminjam serta mengembalikan pinjaman tepat pada waktu yang sudah ditentukan, tentunya dengan 
mengembalikan pokok yang sudah di pinjam tanpa adanya penambahan yang di syaratkan (riba). Pelarangan atas riba dalam surat Al-Baqarah ayat 275 memiliki arti bahwa uang yang dipinjamkan harus tanpa adanya harapan akan pengembalian yang melebihi jumlah pokoknya. Dalam hal ini setiap peminjam yang menuntut atau menetapkan keuntungan tidaklah bersifat sah. Dalam pelunasan hutang pun harus memerhatikan waktu jatuh tempo yang sudah di berikan. Menurut Imam Malik, hal ini seperti halnya ketika seseorang yang memberikan waktu lebih panjang ketika piutangnya telah jatuh tempo dan menambahkan jumlah hutang (debt reschedulling) kepada debitur yang menjadikannya akad ini tergolong dalam riba.

Secara terminologi hutang ialah sejumlah uang yang diberikan/dipinjamkan kepada orang membutuhkan untuk keperluan kebutuhan dia dengan kesepakatan untuk mengembalikan uang tersebut kepada peminjam dengan ketentuan dan kesepakatan tanpa adanya penambahan keuntungan. Adapun hutang piutang (Al Qardl) adalah memberikan sesuatu kepada seseorang dengan perjanjian dia akan membayar yang sama. Pengertian sesuatu yang telah di jelaskan dalam surat Al Maaidah ayat 2:

"Hai orang-orang yang beriman, janganlah kamu melanggar syi'arsyi'ar Allah, dan jangan melanggar kehormatan bulan-bulan haram, jangan (mengganggu) binatang-binatang had-ya, dan binatangbinatang qalaa-id, dan jangan (pula) mengganggu orang-orang yang mengunjungi Baitullah sedang mereka mencari kurnia dan keridhaan dari Tuhannya dan apabila kamu telah menyelesaikan ibadah haji, maka bolehlah berburu. Dan janganlah sekali-kali kebencian(mu) kepada sesuatu kaum karena mereka menghalang-halangi kamu dari Masjidil haram, mendorongmu berbuat aniaya (kepada mereka). Dan tolongmenolonglah kamu dalam (mengerjakan) kebajikan dan takwa, dan jangan tolong-menolong dalam berbuat dosa dan pelanggaran. Dan bertakwalah kamu kepada Allah, sesungguhnya Allah amat berat siksa-Nya".

Konsep hutang sesuai dengan syariat Islam menurut Muhammad Akram Khan adalah salah satu konsep ekonomi Islam dalam bentuk yang lebih tepat ialah Al-qardhul Hassan. hutang piutang dalam bentuk ini dengan dukungan gadai (rahn) dapat digunakan untk keperluan sosial maupun komersial. Dimana dalam hal ini peminjam mempunyai dua pilihan yaitu, memilih qardhul hassan (menerima pemberi pinjaman) atau penyandang dana ( $r a b b$ al-mal) sebagai mitra usaha dalam perjanjian mudharabah (Sarwat, 2019: 284).

Hukum hutang piutang pada dasarnya diperbolehkan dalam syariat Islam. Orang yang memberikan hutangpun kepada orang lain yang sangat membutuhkan ialah hal yang sangat disukai dan dianjurkan. Karena dalam perbuatan tersebut terdapat pahala yang besar. Adapun dalil yang menjelaskan mengenai hutang piutang dapat dijelaskan sebagai berikut: 
"Dan tolong-menolonglah kamu dalam (mengerjakan) kebajikan dan takwa, dan jangan tolong menolong dalam berbuat dosa dan pelanggaran. Dan bertakwalah kamu kepada Allah, sesungguhnya Allah amat berat siksa-nya." (QS. AIMaidah: 2)

Ayat tersebut menjelaskan bahwa setiap umat manusia dapat saling tolong-menolong sesama manusia. Hal ini dikarenakan manusia tidak akan bisa hidup sendiri tanpa adanya bantuan dari orang lain. Namun terkadang jika tolong menolong dilakukan dengan niat yang begitu baik dan ikhlas terkadang menimbulkan suatu permasalahan dikemudian hari.

Hutang merupakan suatu yang biasa terjadi dalam kehidupan begitu pula dalam ajaran Islam. Hal ini dijelaskan pada awal surat al-Baqarah ayat 282, dijelaskan bahwa jika seseorang ingin berhutang kepada pihak lain dalam jangka waktu tertentu, maka hendaklah ia mencatatnya. Sehingga dapat disimpulkan bahwa hutang ialah hal yang diperbolehkan selama memenuhi prinsip-prinsipnya. Prinsip-prinsip tersebut dapat dijelaskan sebagai berikut: (Aziz, 2016: 133)

1. Harus didasari bahwa hutang itu merupakan alternatif terakhir ketika segala usaha untuk mendapatkan dana secara halal mengalami kebuntuan. Terdapat unsur keterpaksaan di dalamnya dan bukan unsur kebiasaan. Hal ini merupakan dua hal yang berbeda. Keterpaksaan menecerminkan semangat membangun kemandiriaan dan berusaha mengoptimalkan potensi yang ada semaksimal mungkin. Namun karena keterbatasan yang tidak sanggup diatasi akhirnya memilih jalan hutang.

2. Jika terpaksa berhutang, jangan berhutang di luar kemampuan.

Dalam syariah disebut dengan ghalabatid dayn atau terbelit hutang. Ghalabatid dayn ini akan menimbulkan efek yang besar, yaitu qahrir rijal (mudah dikendalikan pihak lain). Oleh karenanya Rasulullah SAW, selalu memanjatkan doa agar beliau senantiasi dilindungi dari penyakit ghalabatid dayn yang menyebabkan harga diri menjadi hilang (Huda, 2012: 260-261).

3. Jika hutang telah dilakukan, harus ada niat untuk membayarnya. Harus mempunyai komitmen untuk mengembalikan hutang (Iska, 2012: 179). Memperlambat membayar hutang bagi yang mampu merupakan sebuah kezaliman, sehingga diperbolehkan untuk mempermalukannya. Dalam konteks mikro, akan sangat mudah menerapkan prinsip ini. Misalnya, pengusaha yang tidak mau membayar hutang boleh saja dipermalukan dengan cara menyita asetnya, serta dilarang berpergian ke luar negeri atau menghukum dengan hukuman yang berat.

Dalam perspektif fikih terdapat dua pendapat terkait budget defisit yang ditutup dengan external financing. Pandangan pertama mengatakan bahwa negara tidak diperbolehkan menutup budget deficit dengan melakukan external financing dalam bentuk hutang luar negeri. Hal ini didasari pada pertimbangan 
preventif bahwa mekanisme pinjaman hutang luar negeri menggunakan sistem bunga, sedangkan dalam Islam, bunga dalam bentuk apapun baik konsumsi atau produksi dan besar atau kecil secara tegas dilarang.

Pendapat kedua mengatakan bahwa hutang diperbolehkan jika kondisi yang sudah mendesak dan digunakan untuk kepentingan umum. Menurut Al Ghazali, pinjaman publik harus dikaitkan dengan kepentingan sektor publik dan dibolehkan dengan syarat negara mengantisipasi pendapatan di masa yang akan datang untuk membayar hutang tersebut. Selain itu, menurut Beik (2015) hutang negara harus memiliki prinsip diperbolehkannya berutang jika memang tidak ada sumber lain yang mencukupi kebutuhan, pinjaman harus sesuai dengan kemampuan negara untuk membayarnya (di masa mendatang), dan hutang publik tidak boleh terdapat unsur riba di dalamnya. Jika pinjaman negara digunakan untuk konsumtif dan tidak mengantisipasi kemampuan negara dalam membayarnya, maka ini jelas tidak di perbolehkan.

Dalam ilmu ekonomi pun, praktik external financing dari luar negeri memiliki perbedaan pendapat. Sebagian besar ahli ekonomi konvensional meyakini bahwa saat pemerintah menjalankan kebijakan budget deficit, konsumen yang memiliki pendapatan lebih tinggi akibat berkurangnya penerimaan pajak akan merespon dengan meningkatkan konsumsinya di masa depan sehingga dapat meningkatkan pertumbuhan negara. Namun, sebagian ekonom yang memiliki pandangan Ricardian Equivalence juga berpendapat bahwa hutang luar negeri dengan asumsi konsumen yang forward-looking akan berpikir rasional terkait konsumsi di masa depannya sehingga membuatnya menahan konsumsi saat ini untuk menggantikan beban penerimaan pemasukan negara di periode selanjutnya, hal ini didasari pemahaman bahwa hutang pemerintah sama dengan pajak di masa depan. Selain itu, beberapa ekonom berpendapat secara umum hutang luar negeri dalam jangka panjang dapat menyebabkan terjadinya debt overhang (Krugman, 1988 dan Sachs, 1988) dan crowding out effect (Patenio dan Agustina, 2007) yang membuat hutang dalam kondisi tertentu justru memiliki korelasi negatif terhadap pertumbuhan ekonomi.

\section{B. Utang Negara}

Dalam rangka menghadapi bonus demografi di sekitar tahun 2020 - 2030, saat ini Indonesia melakukan peningkatan pembangunan negara agar dapat memanfaatkan bonus tersebut sehingga tercapainya percepatan usaha Indonesia mencapai developed country. Untuk mencapai percepatan usaha tersebut, pemerintah harus menambahkan jumlah belanja negara. Di dalam APBN 2017 menargetkan pendapatan negara sebesar Rp1.750,3 triliun dengan belanja Rp2.080,5 triliun. Artinya, kurangnya pendapatan negara membuat pemerintah Indonesia melakukan pinjaman luar negeri untuk membiayai belanja tersebut, 
baik dari negara lain maupun dari lembaga keuangan internasional. Ekonomi Islam sebagai ilmu pengetahuan memiliki pembahasan dan cara tersendiri terkait pembiayaan pembangunan ekonomi.

Menurut Undang-Undang Nomor 1 Tahun 2004 mengenai Perbendaharaan Negara dijelaskan bahwa hutang negara ialah jumlah uang yang wajib dibayar pemerintah pusat atau kewajiban pemerintah pusat yang dapat dinilai dengan uang berdasarkan peraturan perundang-undangan yang berlaku, perjanjian, atau berdasarkan sebab lain yang sah.

Munculnya hutang negara disebabkan oleh berbagai faktor. Salah satunya ialah ketertinggalan infrastruktur dan masalah konektivitas yang menimbulkan tingginya biaya ekonomi yang ditanggung masyarakat. Dalam hal ini yang menjadi dasar pemerintah untuk meningkatkan pembangunan infrastruktur demi mengejar ketertinggalan dan meningkatkan pertumbuhan ekonomi Negara. Pemerintah saat ini mengambil kebijakan fiskal ekspansif dimana Belanja Negara lebih besar dibanding dengan Pendapatan Negara untuk mendorong perekonomian tetap tumbuh. (DJPPR, n.d.)

Dalam hal kebijakan belanja negara yang ekspensif pemerintah memprioritaskan belanja produktif untuk sektor infrastruktur, kesehatan, serta pendidikan. Pemerintah dalam hal ini melakukan besarnya belanja negara untuk memberikan suatu stimulus bagi perekonomian, serta masih belumnya terpenuhi dari penerimaan negara seperti pajak, PNBP, bea cukai, dan hibah. Konsekuensi yang terdapat dari kurangnya antara pendapatan dan belanja negara ialah defisit APBN.

Menurut Supatmoko (2013), terdapat beberapa macam hutang negara dapat dijelaskan sebagai berikut:

1. Hutang dengan jaminan dan tanpa jaminan, yang terdiri atas;

Reproductive debt dan dead weight debt. Reproductive debt adalah hutang yang dijamin seluruhnya dengan kekayaan negara yang berutang atas dasar nilai sama besarnya. Sedangkan dead weight debt adalah hutang yang tanpa disertai dengan jaminan kekayaan.

2. Utang sukarela dan hutang paksa.

a. Utang paksa ialah hutang yang pengumpulannya dapat dipaksakan. Adanya sanering uang rupiah dengan cara menggunting uang kertas jadi dua dan yang dianggap berlaku sebagai alat tukar dan satuan hitungnya adalah separuhnya. Diamana separuhnya atau sisanya dinyatakan sebagai pinjaman pemerintah pada masyarakat dalam bentuk obligasi negara. Dalam hal ini masyarakat dipaksa memberikan pinjaman kepada pemerintah. 
b. Utang sukarela ialah para pemberi pinjaman bebas menyerahkan dananya tergantung pada kemauan mereka sendiri, namun jumlah yang di dapat oleh negara biasanya tidak begitu besar.

3. Utang dalam negeri dan hutang luar negeri.

a. Utang luar negeri pemerintah ialah hutang yang dimiliki oleh pemerintah pusat, terdiri dari hutang bilateral, multilateral, fasilitas kredit ekspor, komersial, leasing dan Surat Berharga Negara (SBN) yang diterbitkan di luar negeri yang dimiliki oleh bukan penduduk. Pinjaman luar negeri ini ialah setiap penerimaan negara baik dalam bentuk devisa atau devisa yang dirupiahkan, rupiah, maupun dalam bentuk barang/jasa yang diperoleh dari pemberi pinjaman luar negeri yang harus dibayar kembali dengan persyaratan tertentu. hutang dalam negeri adalah hutang yang berasal dari orang-orang atau lembaga-lembaga sebagai penduduk negara itu sendiri.

b. Utang dalam negeri dapat berupa paksaan maupun sukarela. hutang dalam negeri hanya mencakup pemindahan kekayaan didalam masyarakat itu sendiri, baik pada saat terjadinya hutang, maupun terjadinya pembayaran bunga dan pengembalian cicilan hutang. (Satya, 2015)

Dalam ekonomi islam terdapat dua pandangan berbeda tentang hutang luar negeri sebagai alternatif untuk menutupi defisit anggaran negara. Dapat dijelaskan sebagai berikut:

1. Pandangan pertama berpendapat membolehkan adanya budget deficit yang ditutup dengan external financing, selama bentuk dan mekanismenya disesuaikan dengan ketentuan dan prinsip syariah yang ada. Dilatarbelakangi oleh fakta historis bahwa bekerjasama dengan pihak lain dalam suatu usaha diperbolehkan, bahkan dianjurkan. Dalam hal ini akad atau kerjasama yang dapat dipergunakan ialah mudharabah, musyarakah, murabahah, dan lainlain, dapat dikembangkan sebagai bentuk external financing dalam anggaran negara.

Bentuk-bentuk tersebut pada prinsipnya bersifat flow creating equity dari pada flow creating debt, dimana mulai banyak diimplementasikan oleh lembaga-lembaga keuangan internasional. Islamic Development Bank (IDB) telah banyak membiayai proyek di negara-negara Islam dengan menggunakan skema tersebut. Dibandingkan dengan hutang, penyertaan modal dipandang lebih, konstruktif, proporsional dan fair dalam pembiayaan, karena terdapat pembagian perolehan dan resiko (profit-loss sharing).

2. Pandangan kedua, mengatakan bahwa negara tidak diperbolehkan menutup budget deficit dengan melakukan hutang luar negeri. Hal ini didasari pada pertimbangan preventif bahwa mekanisme pinjaman hutang luar negeri menggunakan sistem bunga, sedangkan dalam islam, bunga dalam bentuk 
apapun baik konsumsi atau produksi dan besar atau kecil secara tegas dilarang. (Muhaimin, 2000)

\section{PEMBAHASAN}

\section{A. Dampak dan Resiko Hutang}

Penelitian yang dilakukan (Ramadhan \& Padjadjaran, 2019) data jumlah total hutang luar negeri Indonesia menurut Bank Indonesia dan data total Produk Domestik Bruto BPS mengindikasikan bahwa hutang luar negeri dan pertumbuhan ekonomi melalui PDB berhubungan positif di Indonesia. Berikut merupakan data hutang luar negeri dan PDB Indonesia dalam 9 tahun terakhir:

Tabel 1. Data Utang Luar Negeri Indonesia

\begin{tabular}{|c|c|}
\hline Tahun & $\begin{array}{c}\text { Utang Luar Negeri Indonesia (juta } \\
\text { USD) }\end{array}$ \\
\hline 2010 & 202.413 \\
\hline 2011 & 225.375 \\
\hline 2012 & 252.364 \\
\hline 2013 & 266.109 \\
\hline 2014 & $293.328,00$ \\
\hline 2015 & $310.730,00$ \\
\hline 2016 & $320.006,00$ \\
\hline 2017 & $352.469,00$ \\
\hline 2018 & $375.491,00$ \\
\hline
\end{tabular}

\begin{tabular}{|c|c|}
\hline Tahun & $\begin{array}{c}\text { Produk Domestik Bruto (triliun } \\
\text { rupiah) }\end{array}$ \\
\hline 2010 & 6864,1 \\
\hline 2011 & 7831,7 \\
\hline 2012 & 8651,7 \\
\hline 2013 & 9546,1 \\
\hline 2014 & $10.569,70$ \\
\hline 2015 & $11.526,30$ \\
\hline 2016 & $12.401,70$ \\
\hline 2017 & $13.587,20$ \\
\hline 2018 & $14.837,30$ \\
\hline
\end{tabular}

Sumber : BI \& BPS

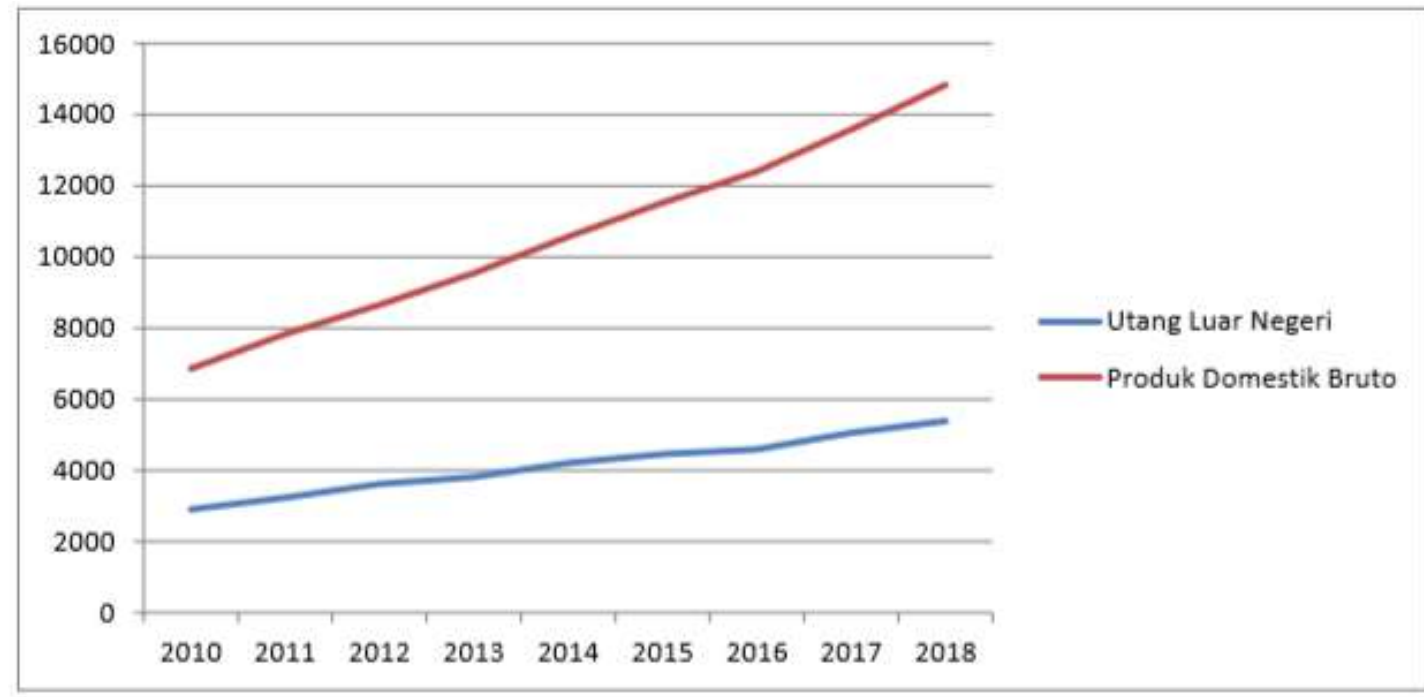

Gambar 1. Grafik Utang Luar Negeri Indonesia

Dari data tersebut dapat dijelaskan bahwa pada tahun 2010-2018 untuk hutang Luar Negeri Indonesia dalam juta USD mengalami peningkatan disetiap tahunnya. Diaman pada tahun 2010 hutang luar negeri indonesia sebesar USD 202.413 juta dan terus meningkat setiap tahunnya, sampai pada tahun 2018 
hutang luar negeri Indonesia sebesar USD 375.491,00 juta. Kemudian untuk Produk Domestik Bruto dalam triliun rupiah pada tahun 2010 sebesar Rp 6864, 1 triliun dan terus mengalami peningkatan setiap tahunnya sampai pada tahun 2018 produk domestik bruto sebesar Rp 14.837,30 triliun.

Dalam hal ini grafik diatas menunjukan hubungan variabel hutang luar negeri dan Produk Domestik Bruto Indonesia dalam triliun rupiah, terlihat bahwa hutang luar negeri dan PDB berhubungan positif dan berbanding lurus terhadap pertumbuhan ekonomi. Hal tersebut dapat ditunjukan pada trend kedua variabel yang positif meningkat di 9 tahun terakhir pada tahun 2010-2018.

Dalam 4 tahun terkahir, APBN cukup mendukung pertumbuhan ekonomi yang berkualitas dan berdampak pada menurunnya tingkat kemiskinan. Menurut (kemenkeu, 2018) tingkat kemiskinan turun dari 11,25\% pada Maret 2014 menjadi $9,82 \%$ pada maret 2018. Tingkat pengangguran terbuka juga mengalami penurunan dari 5,70\% pada Februari 2014 menjadi 5,34\% pada Agustus 2018. Turunnya pengangguran didukung oleh program pemerintah dalam menciptakan lapangan kerja, seperti iklim usaha yang sehat, kemudahan, dan insentif bagi pelaku usaha dan pembangunan proyek infrastruktur. Sehigga dapat disimpulkan bahwa hubungan hutang luar negeri dan pertumbuhan ekonomi memiliki hubungan yang positif. Hal tersebut dapat terlihat dari pertumbuhan PDB yang meningkat, penurunan kemiskinan dan pengurangan pengangguran.

Hutang negara meskipun diperlukan untuk membiayai pembangunan dan perekonomian juga tetap perlu di waspadai terutama hutang luar negeri. Karena selain dampak positif untuk pertumbuhan ekonomi namun memiliki tingkat resiko yang harus ditanggung. Berbagai resiko yang akan ditanggung yaitu resiko global dan risiko domestik. (Satya, 2015) Risiko global yang pertama terkait dengan capacity to repay meningkat akibat perlambatan ekonomi di emerging market dan masih rendahnya harga komoditas. Resiko kedua refinancing dan beban pembayaran hutang luar negeri meningkat akibat ketatnya likuiditas global. Resiko domestik secara makro seperti meningkatnya vulnerability (DSR, Gross external financing, GDP). Secara mikro terkait dengan risiko currency mismatch, over leverage, dan FX liqudity risks. Indonesia menjadi salah satu negara yang termasuk dalam kelompok fragile five yaitu negara-negara yang memiliki kerentanan tinggi dalam menghadapi kebijakan moneter. Ciri-ciri negara yang masuk fragile five yaitu: current account sedikit atau defisit, cadangan devisa tidak besar, inflasi tinggi, dan budget fiskalnya sedikit.

Adapun konskuensi atau dampak dari kebijakan pemerintah dalam menarik hutang luar negeri yaitu: (Atmadja, 2008)

1. Dalam jangka pendek, pinjaman luar negeri dapat menutup desisit APBN, dan jauh lebih baik dibandingkan jika defisit APBN tersebut harus ditutup dengan pencetakan uang baru, sehingga memungkinkan pemerintah untuk 
melaksanakan pembangunan dengan dukungan modal yang relatif lebih besar, tanpa disertai efek peningkatan tingkat harga umum (inflationary effect) yang tinggi. Dengan demikian pemerintah dapat melakukan ekspansi fiskal untuk mempertinggi laju pertumbuhan ekonomi nasional. Meningkatnya laju pertumbuhan ekonomi berarti meningkatnya pendapatan nasional, yang selanjutnya memungkinkan untuk meningkatnya pendapatan perkapita masyarakat, apabila jumlah penduduk tidak meningkat lebih tinggi. Dengan meningkatnya pendapatan perkapita berarti meningkatkan kemakmuran masyarakat.

2. Dalam jangka panjang, hutang luar negeri dapat menimbulkan permasalahan ekonomi pada banyak negara debitur itu sendiri. Disamping beban ekonomi yang harus diterima rakyat pada saat pembayaran kembali, juga beban psikologis politis yang harus diterima oleh negara debitur akibat ketergantungannya dengan bantuan asing.

\section{B. Pandangan Islam terhadap Hutang}

Dalam Islam terdapat dua pandangan mengenai hutang luar negeri dalam perspektif pembiayaan pembangunan negara. Pandangan pertama memperbolehkan adanya suatu budget deficit yang ditutup dengan external financing, dimana bentuk dan mekanismenya tersebut sudah disesuaikan dan tidak bertentangan dengan ketentuan serta prinsip syariah. Dari adanya fakta historis bahwa bekerjasama dengan pihak lain dalam suatu usaha diperbolehkan, bahkan dianjurkan. Seperti dengan penggunaan akad Mudharabah, musyarakah, murabahah, dan lain-lain, dapat dikembangkan sebagai bentuk external financing dalam anggaran negara.

Dibandingkan dengan hutang, penyertaan modal ini dipandang lebih, konstruktif, proporsional dan adil dalam pembiayaan, karena terdapat pembagian perolehan dan resiko (profit-loss sharing). Kemudiaan untuk pandangan yang ke dua ialah negara tidak diperbolehkan menutup budget deficit dengan melakukan hutang luar negeri. Karena pada pertimbangan preventif bahwa mekanisme pinjaman hutang luar negeri menggunakan sistem bunga, sedangkan dalam islam, bunga dalam bentuk apapun baik konsumsi atau produksi dan besar atau kecil secara tegas dilarang.

Dari pandangan Islam, praktek, proses serta implikasinya dari hutang luar negeri yang diterapkan di Indonesia ini tidak sesuai dengan ajaran Islam. Hal tersebut dapat dijelaskan sebagai berikut: (Muhaimin, 2015)

1. Hutang yang dilakukan didasarkan pada riba. Karena dalam pelaksanaanya hutang yang dilakukan oleh pemerintah Indonesia adanya sistem bunga. Dimana dalam islam adanya penerapan bunga ini mengarahkepada riba yang 
dilarang oleh islam, terlepas dari seberapa rendahnya atau seberapa besarannya bunga tersebut.

2. Hutang luar negri menyebabkan jatuhnya martabat suatu bangsa. Dalam islam mengajarkan untuk senantiasa menjaga integritas dengan baik secara individu maupun bangsa. Dimana dalam hal ini akan kehilangan suatu kebebasan dalam mengatur kebijakan ekonominya akibat adanya tekanan dari pihak yang memberi hutang.

3. Hutang luar negeri melanggar prinsip fair dealing dalam Islam. Karena pada kejadian di masa lampau yang pernah terjadi bahwa tidak ada proses tawar menawar yang adil dalam pemberian hutang. Dalam hal ini tawar menawar terjadi sangat bias ke arah keuntungan negara maju dan kerugian bagi negara penerima.

Dalam hal ini jika pada saat kondisi normal, hutang pasti harus dibayarkan. Namun, dalam kondisi kesulitan, pailit dan krisis yang diderita oleh debitur, alQur'an secara bijak menawarkan solusi yang realistis dan manusiawi. Allah berfirman:

"Dan jika (orang yang berhutang itu) dalam kesulitan, maka berilah tangguh sampai dia berkelapangan. Dan menyedekahkan (sebagian atau semua hutang) itu lebih baik bagimu, jika kamu mengetahui." (Q.S Al-Baqarah: 280)

Ayat tersebut menawarkan tiga alternatif penyelesaian terhadap krisis hutang: (Muhaimin, 2015).

1. Penangguhan pembayaran hutang sampai debitur mampu mengembalikan hutangnya. Dalam konteks hutang luar negeri perlu diadakan penjadwalan ulang (rescheduling) pembayaran hutang bersama dengan lembaga dan negara kreditur.

2. Peringanan pembayaran hutang sesuai dengan kemampuan debitur. Pemberian keringanan ini besar kecilnya atau prosentasinya disesuaikan dengan kemampuan dan kesepakatan kedua belah pihak.

3. Pembebasan seluruh hutang. Dalam kondisi dimana debitur tidak mampu membayar hutang, adalah sangat manusiawi dan terpuji bila kreditur mau membebaskan debitur dari seluruh hutangnya.

\section{Hutang Luar Negeri dalam Perspektif Islam}

Hutang merupakan perwujudan dari suatu pinjaman yang dilakukan oleh pemerintah. Biasanya transaksi hutang atau pinjaman ini terjadi, manakala pendapatan negara dalam keadaan terbatas, dan tidak imbang dengan meningkatnya kebutuhan akan anggaran pembangunan. Dengan kata lain, penerimaan negara yang ada masih belum mampu berpacu dengan kebutuhan pengeluaran negara yang diinginkan, atau pemerintahan tidak punya uang yang cukup. Setidaknya, kesalahan tersebut tidak harus dibayar dengan berutang. 
Sebenarnya untuk menambah pos penerimaan negara ada dua cara yaitu; menarik dana dari dalam negeri berupa pajak atau surat hutang, dan menarik dana dari luar negeri dalam bentuk investasi atau pinjaman. Penarikan dana berupa pajak yang belum dibayarkan oleh wajib pajak seringkali menghambat pendapatan pemerintah. Idealnya, kesadaran wajib pajak tinggi atau kalau tidak dilakukan penarikan oleh pihak pemerintah. Daripada pemerintah lebih memilih menarik dana dari luar negeri. Mencermati fenomena hutang, dan supaya stabilitas perekonomian tetap terjaga agar defisit anggaran pendapatan dan belanja negara tidak melampaui batas yang aman. Maka pengelolaaan hutang perlu dilakukan, agar krisis ekonomi yang pernah terjadi tidak terulang kembali di Indonesia. Sehingga perencanaan, implementasi dan pengendalian atas pinjaman menjadi sangat penting adanya.

Menurut definisi yang dirumuskan Development Assistance Commitee (2002) hutang luar negeri adalah bantuan pembangunan secara resmi yang terdiri dari dana yang disediakan oleh pemerintah atas persyaratan konsesional terutama untuk meningkatkan perkembangan ekonomi dan kesejahteraan negara-negara berkembang. Hutang luar negeri atau pinjaman luar negeri adalah sebagian dari total hutang suatu negara yang diperoleh dari para kreditor di luar negara tersebut. Menurut Setiawan (2011) hutang luar negeri Indonesia terdiri dari:

a. Hutang luar negeri pemerintah Hutang yang dimiliki leh pemerintah pusat, terdiri dari hutang bilateral, multilateral, fasilitas kredit ekspor, komersial, leasing, dan SBN (Surat Berharga Negara) baik yang diterbitkan di luar negeri maupun di dalam negeri yang bukan dimiliki oleh penduduk.

b. Hutang luar negeri bank swasta Hutang yang dimiliki oleh Bank Indonesia, yang diperuntukkan dalam rangka mendukung neraca pembayaran dan cadangan devisa. Selain itu ada juga hutang kepada pihak bukan penduduk yang telah menempatkan dananya pada Sertifikat Bank Indonesia.

c. Hutang luar negeri swasta Hutang luar negeri penduduk kepada bukan penduduk dalam valas dan atau rupiah Indonesia berdasarkan perjanjian hutang (loan agreement) atau perjanjian lainnya, kas dan simpanan milik bukan penduduk, dan kewajiban lainnya kepada bukan penduduk.

Adapun motif hutang luar negeri menurut Setiawan (2011) adalah kurangnya tabungan dalam negeri (saving investment gap). Kekurangan tabungan ini tidak lain karena rendahnya tingkat pendapatan penduduk, di samping itu juga karena sistem keuangan yang belum memadai. Motif kedua adalah kurangnya kemampuan untuk menghasilkan devisa (foreign exchange gap). Untuk melakukan transaksi perdagangan internasional diperlukan devisa, sementara itu kemampuan dalam menghasilkan devisa masih rendah.

Menurut Beik (2009) dalam Huda (2016) hutang mempunyai prinsip tertentu yaitu: 
a. Hutang merupakan alternatif terakhir ketika segala usaha untuk mendapatkan dana secara halal dan tunai mengalami kemandekan. Ada unsur keterpaksaan di dalamnya dan bukan unsur kebiasaan. Dalam konteks negara, maka apakah kebijakan hutang yang telah dilakukan pemerintah Indonesia telah memenuhi unsur keterpaksaan atau justru menjadi kebiasaan.

b. Jika terpaksa berhutang, jangan berhutang di luar kemampuan. Inilah yang dalam istilah syariah disebut dengan ghalabatid dayn atau terlilit hutang. Hal ini akan menimbulkan efek yang besar yaitu qahrir rijal. Atau mudah dikendalikan pihak lain. Oleh karena itu Rasulullah memanjatkan doa agar beliau senantiasa dilindungi dari penyakit ghalabatid dayn yang akan menyebabkan harga diri menjadi hilang. Apalgi, jika yang mengendalikan adalah musuh yang mempunyai niat buruk dan kebencian luar biasa. Dalam konteks negara harus dilihat apakah selama ini sudah sesuai dengan kemampuan bangsa.

c. Jika hutang telah dilakukan, harus ada niat untuk membayarnya. Dalam konteks makro, terkait dengan hubungan antar negara jika Indonesia berusaha melalkukan upaya rescheduling hutang atau bahkan penghapusan hutang maka upaya tersebut adalah hal yang sah-sah saja apalgi ternyata manfaat hutang Indonesia selama ini lebih banyak dinikmati asing. Ekonom Drajad H. Wibowo mengatakan bahwa $70 \%$ manfaat hutang kembali ke kreditur.

Hutang luar negeri adalah sebagian dari seluruh hutang negeri yang diperoleh dari kreditor luar negeri. Penerima hutang luar negeri bisa dari pemerintahaan, perusahaan maupun individual, sementara bentuk hutang dapat berupa hutang maupun jasa yang diperoleh dari negara lain, perusahaan luar, maupun Lembaga keuangan dunia seperti Bank Dunia, Asian Developed Bank (ADB) dan International Monetary Fund (IMF). Indonesia sendiri telah berhutang kepada beberapa negara dan lembaga keuangan dunia. Jika bisa dilihat dari data riset terbaru pada tahun 2018 total hutang Indonesia mendekati angka US\$ 358,6 miliar.

Dari perspektif pandang Islam secara umum ada dua pandangan terhadap hutang luar negeri. Pandangan pertama hutang luar negeri diperbolehkan asalkan bersistemkan external financing, karena dalam sistemnya sesuai syariah dan bertujuan untuk saling membantu. Seperti mudharabah, musyarakah, murabahah, dll. Sehingga dapat disimpulkan dalam pandangan pertama bahwa hutang luar negeri diperbolehkan dengan alasan untuk saling membantu. Adapun untuk pandangan kedua hutang luar negeri secara tegas dilarang, karena khususnya dizaman ini dimana mayoritas negara kreditur adalah bukan negara Islam. Sehingga akan terjadi riba didalam hutang luar negeri, padahal sudah diterangkan secara jelas bahwa hutang ataupun hal transaksi ekonomi yang 
terdapat riba didalamnya adalah haram. Jika dilihat ulang data di atas, tidak dapat dipungkiri bahwa negara Indonesia banyak melakukan pinjaman hutang luar negeri kepada negara kreditur yang non islam, sehingga sudah pasti mengandung riba. Jadi hutang luar negeri pada saat ini karena banyak negara non muslim yang menjadi kreditur, maka hutang luar negeri secara mayoritas adalah haram.

Menurut Tokoh Islam kontemporer masalah hukum hutang luar negeri terdapat tiga pendapat. Pertama menurut Mannan, Negara Islam Modern harus mengambil langkah hutang luar negeri untuk memenuhi kebutuhan yang ada. Pinjaman tersebut boleh dari lembaga atau negara non muslim, dengan syarat negara atau lembaga kreditur tidak memberi beban bunga atau riba. Sehingga Negara Indonesia yang mayoritas beragama Islam boleh saja meminjam ke negara atau Lembaga non Islam, akan tetapi dengan syarat bebas bunga atau riba. Kedua menurut Umar Chapra hutang luar negeri adalah cara yang tidak efektif, selain tidak lepas dari unsur bunga hal tersebut juga memberatkan generasi berikutnya untuk membayar hutang tersebut. Menurut Umar Chapra cara terbaik selain hutang luar negeri adalah dengan menaikan pajak. Sehingga dapat disimpulkan menurut Umar Chapra hutang luar negeri tidak efektif dan sebagai solusinya adalah memanfaatkan pajak. Adapun untuk yang ketiga yaitu Abdullah Qadim Zallum dengan cara yang hampir sama dengan Umar Chapra bahwasanya hutang luar negeri bukanlah cara yang tepat, akan tetapi pajak atau kewajiban Kaum Muslimin yang harus diutamakan. Sehingga menurut Abdullah Qadim Zallum bahwasanya hutang negara bukan menjadi solusi utama, akan tetapi solusi utama adalah kewajiban kaum muslimin itu sendiri.

Menurut Susan George (1992) dalam Atmadja (2000), hutang luar negeri secara pragmatis justru menjadi bomerang bagi negara penerima (debitur). Perekonomian di negara-negara penerima hutang tidak menjadi semakin baik, melainkan bisa semakin hancur. Hal tersebut merupakan salah satu kesimpulan dari hasil penelitiannya yang menunjukan, bahwa pada tahun 1980-an arus modal yang mengalir dari negara-negara industri maju, yang umumnya merupakan negara kreditur, ke negara-negara yang sedang berkembang dalam bentuk bantuan pembangunan (official development assistance), kredit ekspor, dan arus modal swasta, seperti bantuan bilateral dan multilateral; investasi swasta langsung (PMA); portfolio invesment; pinjaman bank; dan kredit perdagangan (ekspor/impor), lebih kecil daripada arus aliran dana dari negara-negara yang sedang berkembang ke negara-negara maju tersebut dalam bentuk cicilan pokok hutang luar negeri dan bunganya, royalti, deviden, dan keuntungan repatriasi dari perusahaan-perusahaan negara maju yang berada di negara-negara yang sedang berkembang.

Penelitian Susan George tersebut memperkuat argumentasi yang pernah disampaikan G.J. Meier (1970), bahwa arus modal asing dari negara maju ke 
negara dunia ketiga tidak pernah meningkat, dan masalah pelunasan hutang luar negeri semakin memberatkan, karena itu surplus impor yang ditunjang modal asing semakin merosot, dan pengalihan sumber-sumber di luar impor yang didasarkan pada ekspor menjadi relatif tidak penting bagi sebagian besar negara dunia ketiga. Selama kendala devisa ini tidak bisa diatasi, negara kurang maju tidak dapat memenuhi kebutuhan impornya bagi program pembangunan. Akibatnya negara dunia ketiga itu terpaksa menempuh salah satu atau gabungan dari kebijaksanaan yaitu mengurangi laju pembangunan negara, mengembangkan ekspor dan melakukan substitusi impor untuk memperbaiki term of trade, atau merangsang arus bantuan luar negeri lebih besar lagi. (Atmadja, 2000) Akibat semakin banyaknya negara-negara yang terjerumus dalam krisis hutang luar negeri, menyebabkan IMF dan Bank Dunia terpaksa menganjurkan kepada negaranegara tersebut untuk melakukan program penyesuaian struktural (structural adjustment) terhadap perekonomian dalam negeri, misalkan dengan pengurangan atau penghapusan berbagai macam subsidi bahan bakar minyak dan kebutuhan pokok lainnya, penundaan kenaikan gaji pegawai negeri, dan berbagai macam kebijaksanaan kontraksi fiskal lainnya, sebagai syarat utama untuk mendapatkan pengurangan hutang atau memperoleh pinjaman baru. Hal ini terjadi pula di Indonesia (Atmadja, 2000). Secara sederhana, negara tidak lagi mempunyai kebebasan dalam mengatur perekonomiannya karena harus mengikuti anjuran-anjyran dari IMF atau Bank Dunia.

\section{Pembiayaan Pembangunan dalam Ekonomi Islam}

Keuangan negara kebanyakan menganut sistem budget deficit. Untuk mengatasi budget deficit yang biasa dilakukan ialah dengan meningkatkan penerimaan negara melalui pajak dan atau meminjam dana baik dari masyarakat atau pihak lain melalui obligasi atau hutang luar negeri. Tentu hal ini berbeda dengan sistem awal pemerintahan Islam yang lebih menggunakan sistem tradisional. Konsep ini tidak serumit sistem anggaran modern sehingga secara sederhana konsep ini adalah konsep berimbang dalam pengertian pengeluaran dan penerimaan negara adalah sama. Pada era pemerintahan Rasulullah dan khulafaurrasyidin, APBN jarang sekali mengalami budget deficit. Hal ini dikarenakan para pemimpin memegang prinsip bahwa pengeluaran hanya boleh dilakukan apabila ada penerimaan. Hanya terjadi sekali budget deficit yaitu sebelum Perang Hunain, sebelum Fathu Makkah karena banyak orang masuk Islam sehingga pengeluaran zakat lebih besar dari penerimaannya. Hhutang tersebut segera dilunasi setelah perang atau setahun kemudian (Huda, 2016).

Secara bahasa al-qardh berarti al-qoth' (terputus). Harta yang diutangkan kepada pihak lain/orang lain dinamakan qardh karena ia terputus dari pemiliknya (Haroen, 2000). Adapun yang dimaksud dengan hutang piutang adalah 
memberikan sesuatu kepada orang lain dengan perjanjian orang tersebut akan membayar yang sama dengan apa yang dia pinjam dari orang lain (Basri, 2003). Hutang piutang merupakan salah satu mu'amalah yang bercorak ta'awun (pertolongan) kepada orang lain untuk memenuhi kebutuhannya. Sumber ajaran Islam sangat kuat menyerukan prinsip hidup gotong royong seperti ini.

Bahkan al-quran menyebut hutang piutang untuk menolong atau meringankan orang lain yang membutuhkan dengan istilah "mengutangkan kepada Allah dengan hutang baik" (Ghufron, 2002). Disyaratkan untuk sahnya pemberian hutang ini bahwa pemberi hutang adalah orang yang boleh mengeluarkan sedekah. Maka, seorang wali (pengasuh) anak yatim tidak boleh memberikan hutang dari harta anak yatim yang ia asuh tersebut. Disyaratkan juga diketahuinya jumlah dan ciri-ciri harta yang dipinjamkan, agar dapat dikembalikan kepada pemiliknya. Dengan demikian, piutang tersebut menjadi hutang di tangan orang yang meminjam, dan ia wajib mengembalikannya ketika mampu dengan tanpa menunda-nundanya. Adanya pengajuan hutang negara Indonesia untuk pembangunan pertumbuhan ekonomi daerah dengan tujuan untuk pertumbuhan ekonomi daerah sebagai wacanan pertumbuhan ekonomi daerah dari segi pendidikan, ekonomi, kesehatan dan kesejahteraan. Tahun 1997 negara Indonesia sudah memiliki Hutang Luar Negeri dari tahun ke tahun Hutang Negara Indonesia semakin bertambah yang mengakibatkan pertumbuhan ekonomi semakin meningkat akibat adanya pembangunan sarana dan prasarana, kesehatan, pendidikan dan kesejahteran.

Perencanaan pembangunan (development) mengandung pengertian suatu proses yang menyebabkan sesuatu dapat tumbuh, atau menjadi lebih matang atau dewasa. Secara konsep pembangunan islam adalah pembangunan ekonomi yang memang sedikit berbeda dengan pertumbuhan ekonomi, namun walupun telah dibedakan artinya pada akhirnya kedua tersebut. Menurut Sukirno menyatakan bahwa literatur pertumbuhan ekonomi sebagai suatu ukuran kuantitatif yang menggambarkan perkembangan suatu perekonomian dalam suatu tahun tertentu apabila dibandingkan dengan tahun sebelumnya. Perkembangan tersebut selalu dinyatakan dalam bentuk persentase perubahan pendapatan nasional pada suatu tahun tertentu dibandingkan dengan tahun sebelumnya.

Dengan sistem pinjaman luar negeri saat ini yang berbasis bunga dan dampak negatif dari hutang luar negeri yang dapat terjadi, bukan berarti negara Islam (secara demografi) tidak dapat melakukan pembangunan negara dengan sumber modal layaknya negara yang melakukan pinjaman luar negeri. Alternatif sumber pembiayaan pembangunan di ekonomi Islam dapat diperoleh dari dalam negeri maupun luar negeri. Sumber dalam negeri dapat menggunakan berbagai instrumen seperti wakaf dan sukuk, sedangkan sumber luar negeri dapat berupa kerjasama dengan negera lain berdasarkan akad-akad yang sesuai syariah. 
Wakaf merupakan penahanan hak milik atas materi benda untuk tujuan menyedekahkan manfaat, dengan kata lain wakaf bertujuan untuk memberikan manfaat atau harta yang diwakafkan kepada orang yang berhak dan dipergunakan sesuai dengan ajaran agama Islam. Sifat wakaf adalah memberikan manfaat untuk masyarakat serta mendekatkan diri kepada Allah SWT. Infrastruktur yang ingin dibangun dapat dibiayai dengan mekanisme wakaf, hal tersebut sangat dapat dilakukan mengingat potensi wakaf di Indonesia yang sangat besar, yaitu sekitar Rp377 triliun atau 4,2 miliar meter persegi tanah. Pembangunan dilakukan dengan cara menggunakan wakaf tanah sebagai lahan pembangunan infrastruktur dan wakaf tunai yang digunakan untuk permodalan pembangunan infrastruktur. Pembuatan sistem terintegrasi dari pemerintah dalam mempertemukan permintaan wakaf (pengelola wakaf atau nazir) dan penawaran wakaf (pemberi wakaf atau wakif) sangat dibutuhkan, hal tersebut dapat diterapkan dalam Bank Wakaf Ventura yang dimiliki pemerintah. Selain itu, hasil dari operasional wakaf pun dapat menjadi dana wakaf produktif yang dapat terus bertambah pokoknya seperti yang telah dilaksanakan di Singapura, Malaysia, dan Arab Saudi. Di negara non-muslim seperti Singapura, wakaf di kelola oleh Majelis Ulama Islam Singapura (MUIS). MUIS mengelola dana wakaf untuk mempromosikan pendidikan Islam di Asia Tenggara. MUIS juga biasa menangani dan mengembangkan 200 wakaf properti di negara ini, dengan nilai total asset US\$250 juta. Maka hasil dari pendapatan sewa tahunan wakaf ini hingga jutaan dolar, dan membuat Singapura menjadi negara paling maju dalam pengembangan wakaf.

Sukuk negara yang saat ini sedang berkembang di Indonesia juga memiliki potensi yang sangat baik untuk dijadikan sumber utama pembiayaan pembangunan negara, dalam dua penerbitan sukuk negara terakhir, Kementerian Keuangan (Kemenkeu) melaporkan penerbitan sukuk dalam dua seri tersebut berhasil menghimpun dana US\$3 miliar sekitar Rp39,96 triliun, penerbitan sukuk tersebut menjadi yang terbesar dunia di luar negara teluk. Selain itu, saat ini Indonesia pun dikenal sebagai leading sovereign sukuk issuer in the world sehingga sukuk sangat dapat dipertimbangkan untuk dijadikan salah satu instrumen fiskal dalam memenuhi pembiayaan pembangunan

Pinjaman luar negeri tanpa riba juga dapat dilakukan untuk pembangunan infrastruktur yang direncanakan pemerintah dengan bentuk kerjasama yang diperkenankan oleh syariah, seperti mudharabah (profit-loss sharing), musyarakah (partnership), murabahah dan lain sebagainya. Bentuk ini pada prinsipnya lebih bersifat flow creating equity dibanding dengan flow creating debt. Saat ini bentuk tersebut telah dikembangkan oleh lembaga-lembaga internasional, salah satunya adalah Islamic Development Bank dengan memberikan penyertaan modal yang lebih konstruktif, proporsional, dan adil 
dalam kerjasama karena terdapat pembagian keuntungan dan risiko (Profit-Loss Sharing).

Bentuk ini pun berbeda dengan pinjaman berbasis hubungan debiturkreditur, dimana negera debitur dapat diatur oleh kreditur dalam kebijakan ekonomi yang diambil sebagaimana yang terjadi ketika IMF mendikte Indonesia di tahun 1990an, hutang luar negeri melanggar prinsip fair dealing dalam Islam. Dilihat dari proses yang diutarakan terdahulu, tidak ada proses tawar menawar yang adil dalam pemberian hutang. Tawar-menawar yang terjadi sangat bias ke arah keuntungan negara maju dan kerugian bagi negara penerima.

Dengan beberapa sumber pembiayaan untuk pembangunan negara tersebut, hasil yang didapat InsyaAllah tidak hanya berupa pembangunan secara fisik, melainkan memberikan dampak multi-dimensional yang memberikan kemakmuran masyarakat yang adil (societal welfare) dengan masuknya variabel berkah dari Allah Ta'ala. Oleh karena itu, sangat penting bagi pemerintah untuk mempertimbangkan sumber pembiayaan alternatif yang tidak bertentangan dengan syariah dalam melakukan pembangunan negara

\section{SIMPULAN}

Hutang merupakan salah satu instrumen penopang pembiayaan negara dalam kondisi tertentu. Secara prinsip, hutang tidak dilarang dalam Islam. Namun Islam mengatur mekanisme berhutang agar tidak terjebak kepada praktik ribawi. Di antaranya dengan menerapkan mekanisme akad-akad yang sesuai dengan prinsip syariah. Hutang dibolehkan karena dalam berhutang sejatinya terdapat unsur tolong menolong. Untuk itu hutang merupakan solusi alternatif terakhir jika memang berada dalam kondisi tertentu yang mengharuskannya.

Melalui kajian ini, penulis rekomendasikan agar Pemerintah memberikan perhatian yang besar terhadap penerapa hutang. Di samping itu, upaya untuk menerapkan skema akad dan mekanisme yang sesuai dengan prinsip syariah sangat diharapkan, agar pembangunan yang dilakukan dari hutang dapat memberikan manfaat dan maslahat lebih besar bagi masyarakat.

\section{DAFTAR PUSTAKA}

Atmadja, A. S. (2008). hutang LUAR NEGERI PEMERINTAH INDONESIA. Jurnal Akuntansi \& Keuangan Vol. 2, No. 1, Mei 2000: 83 - 94, 2(1), 83-94.

Aziz, A. (2016). ESENSI hutang DALAM KONSEP EKONOMI ISLAM. Bisnis Dan Manajemen Islam, 4(1), 133.

http://journal.iainkudus.ac.id/index.php/Bisnis/article/viewFile/1689/1503

Choirunnisak, C. (2018). hutang Luar Negeri Indonesia dalam Perspektif Ekonomi Syariah. Islamic Banking : Jurnal Pemikiran Dan Pengembangan Perbankan 
Syariah, 4(1), 207. https://doi.org/10.36908/isbank.v4i1.53

Djppr.kemenkeu. (2020). Transaksi Penjualan Surat hutang Negara Dalam Denominasi US Dollar Sebesar USD4,3 Miliar Melalui SEC-Registered Shelf Take-Down.

DJPPR. (n.d.). Menjawab hutang.

Hamid, E. S. (2000). Perekonomian Indonesia Masalah dan Kebijakan Kontemporer. Yogyakarta:UII Press.

Huda, N. dkk. (2012). Dalam Keuangan Publik Islami; Pendekatan Teoritis dan Sejarah. Jakarta: Kencana.

Iska, S. (2012). Sistem Perbankan Sayriah di Indonesia dama Persperspektik Fikih Ekonomi. Yogyakarta: Fajar Media Press.

Kaminsky, G. L. dan A. P. (1996). The Debt Crisis: Lessons of the 1980s for 1990s. Journal of Development Economics, 50, 221.

kemenkeu, D. (2018). Menjawab hutang. Www.Kemenkeu.Go.Id. https://www.kemenkeu.go.id/menjawabutang

KEMENKEURI. (2020). Apbn kita. 36.

Makki, S. (2020). hutang Luar Negeri RI Tembus Rp6.115 T per Akhir Januari. 16 Maret. https://www.cnnindonesia.com/ekonomi/20200316104330-532483755/utang-luar-negeri-ri-tembus-rp6115-t-per-akhir-januari

Muhaimin. (2000). MASALAH HUTANG LUAR NEGERI INDONESIA DAN ALTERNATIF SOLUSINYA DALAM PERSPEKTIF KEBIJAKAN EKONOMI MAKRO ISLAM. 1-22.

Muhaimin, M. (2015). MASALAH HUTANG LUAR NEGERI INDONESIA DAN ALTERNATIF SOLUSINYA DALAM PERSPEKTIF KEBIJAKAN EKONOMI MAKRO ISLAM. At-Taradhi: Jurnal Studi Ekonomi, 5 (2), 6-8. https://jurnal.uinantasari.ac.id/index.php/taradhi/article/viewFile/225/182

Ramadhan, A., \& Padjadjaran, U. (2019). Analisis Pengaruh hutang Luar Negeri terhadap Pertumbuhan Ekonomi di Indonesia Periode 2010-2018. December. Sarwat, A. (2019). Ensiklopedia Fikih Indonesia 7: Muamalat. Jakarta: PT. Gramedia Pustaka Utama.

Satya, V. E. (2015). Manajemen hutang Pemerintah Dan Permasalahannya State Debt Management Analysis : Kajian Vol. 20 No. 1 Maret 2015 Hal. 59 - 74, 5974.

Supatmoko. (2013). Keuangan Negara Dalam Teori Dan Praktik (keenam). BPFE. 